SAD / JSR

Sosyoloji Araştırmaları Dergisi / Journal of Sociological Research

Cilt / Volume 20 Sayı / Number 2 (Ekim / October 2017) : (173-199)

\title{
UYUŞTURUCU SATICILARI: DAMGALANMIŞLARIN SUÇ VE CEZA ANLAYIŞI
}

\section{Ruken MACIT ${ }^{1}$}

\section{$\ddot{O} Z$}

Uyuşturucu ticareti, toplumsal, siyasal ve ekonomik değişkenleri içeren çok boyutlu bir sosyal problemdir. Uyuşturucu ticaretinin önemli aktörlerinden biri kuşkusuz uyuşturucu satıcılarıdır. Bu çalışmada, eski hükümlü 15 uyuşturucu satıcısıyla derinlemesine mülakatlar yapılmıştır. Bu çerçevede, uyuşturucu pazarının ana unsurlarından biri olan uyuşturucu satıcılarının, uyuşturucu maddesine olan bakış açıları, cezaların caydırıcılıkları konusundaki düşünceleri ve bir suçlu olarak toplum tarafından nasıl damgalandıkları ele alınmıştır. Araştırma bulgularına göre, uyuşturucu satıcılarının uyuşturucu madde konusundaki olumsuz düşünceleri ilgi çekmektedir. Bununla birlikte, eski hükümlülerin bakış açısından tek başına cezaların caydırıcılığının yeterli olmadığı ve toplum tarafından damgalanmalarının suçlu davranışının tekrarlanma olasılıklarını arttırdığına dair görüşlere ulaşılmıştır.

Anahtar Kelimeler: Uyuşturucu, Uyuşturucu Satıcıları, Sembolik Etkileşimcilik, Damgalama Teorisi

${ }^{1}$ Arş. Gör., Mersin Üniversitesi, Edebiyat Fakültesi, Sosyoloji Bölümü

$\mathrm{SAD} / \mathrm{JSR}$

Cilt / Volume 20 Say / Number 2 


\section{DRUG DEALERS: STIGMATIZED'S VIEW OF CRIME AND PUNISHMENT}

\section{ABSTRACT}

Drug trade, involving social, politics and economic variables, is a multidimensional social problem. One of the key actors of drug trade is undoubtedly drug dealers. In this research, thoroughly interviews were conducted with 15 drug dealers who were formerly convicted. In this context drug dealers', one of the main elements of the drug market, perspectives on drug, thoughts on deterrence of punishment and how they are stigmatized by society as a criminal were discussed. According to research findings, drug dealers' negative thoughts on drug substance are drawn interest. However, from ex-convict's perspectives, the deterrence of punishment is not sufficient and the views that their stigmatization increases the likelihood of repetition of their criminal behavior have been reached.

Keywords: Drug, Drug Dealers, Symbolic Interaction, Labeling Theory 


\section{GİRIŞ}

Günümüzde uyuşturucu ticareti toplumun birçok kesimini etkileyen farklı boyutları olan önemli bir konudur. Yasa dışı uyuşturucu pazarları, farklı düzeylerde büyük miktarlarda para sağlayan karmaşık üretim ve dağıtım sistemleridir. Uyuşturucu suçları da Türkiye'de dâhil olmak üzere birçok ülkede giderek yaygınlık gösteren suçlar arasında yer almaktadır.

Uyuşturucu madde kavramı esas itibarı ile dört temel faaliyeti ve buna bağlı olarak da dört temel grubu bünyesinde barındırmaktadır. Bunlar; uyuşturucu madde üretimi ve üreticileri, uyuşturucu madde nakli ve kuryeler, uyuşturucu madde satıcısı ve sokak satıcıları ve uyuşturucu madde kullanımı ve kullanıcılarıdır. Belirtilen faaliyetler ve gruplar iç içedir ve bir şahıs aynı zamanda her dört grubun da üyesi olabilmektedir (Gökçegöz \& Usta, 2012'dan aktaran Karakaya, 2013, s. 558). Bu araştırmada, kat1lımcılar uyuşturucu madde kaçakçıları, uyuşturucu madde üreticileri, uyuşturucu madde kuryeleri, uyuşturucu madde satıcıları ve sokak satıcılarından oluşmaktadır.

Uyuşturucu ticareti sadece satıcının ve kullananın etkilendiği bir sosyal problem değildir. Avrupa Uyuşturucu Pazarı Raporu'na (EU Drug Market Reports, 2016, s. 23) göre yasadışı uyuşturucu pazarının sonuçları kapsamlı olarak değişmekte ve uyuşturucu kullanımının zararlarının ötesine geçmektedir. Meşru işletmeler ve ekonomi üzerindeki etkileri, çeşitli suç faaliyetleri ve terör, devlet kurumlarındaki yolsuzluklar ve bunların toplumsal yönleri olmak üzere birçok etkileri söz konusudur. Bundan dolayı da uyuşturucu ticareti tek yönlü değil, birçok yönden incelenmesi gereken kapsamlı bir konudur.

Avrupa'da her yıl bir milyonun üzerinde yasa dışı uyuşturucu madde ele geçirilmektedir. Bunların çoğu kullanıcılardan ele geçirilen küçük miktarlarda uyuşturuculardır; bunun yanı sıra kaçakçılardan ve üreticilerden ele geçirilen çok kilogramlı gönderiler ele geçirilen genel uyuşturucu miktarlarının diğer önemli kısmını oluşturmaktadır (Avrupa Uyuşturucu Raporu, 2016, s. 19). Türkiye coğrafi konumu itibariyle afyon türevi bağımlılık yapıcı maddelerin üretim bölgeleri olan Afganistan ve bölgesinden, 
tüketim bölgesi olan Avrupa Ülkelerine yasa dışı sevkiyatında transit ülke olarak ve bu transit geçişe bağlı olarak ortaya çıkan etkileşim nedeniyle de kullanım boyutunda etkilenmektedir. Bunun tersi bir trafik, Avrupa ülkelerinden Türkiye'ye ve Türkiye üzerinden Arap Yarımadası'ndaki bazı ülkelere doğru görülmektedir. (EMCDDA Ulusal Raporu, 2007, s. 11).

Türkiye'de uyuşturucu cezaları 2014 yılında yapılan değişikliklerle birlikte eskiye oranla ağırlaştırılmıştır. Türk Ceza Kanunu 5237 Sayılı 188. maddesine göre: "Uyuşturucu veya uyarıcı maddeleri ruhsatsız veya ruhsata aykırı olarak imal, ithal veya ihraç eden kişi, (Değişik ibare: 6545 - 18.6.2014 / m.66) “yirmi yıldan otuz yıla kadar" hapis ve yirmi bin güne kadar adli para cezası ile cezalandırılır. Uyuşturucu veya uyarıcı maddeleri ruhsatsız veya ruhsata aykırı olarak ülke içinde satan, satışa arz eden, başkalarına veren, (Ek ibare: 5377 - 29.6.2005 / m.22) "sevk eden," nakleden, depolayan, satın alan, kabul eden, bulunduran kişi, (Değişik ibare: 6545 - 18.6.2014 / m.66) “On yıldan az olmamak üzere” hapis ve yirmi bin güne kadar adli para cezası ile cezalandırılır. (Ek cümle : 6545 - 18.6.2014 / m.66) Ancak, uyuşturucu veya uyarıcı madde verilen veya satılan kişinin çocuk olması hâlinde, veren veya satan kişiye verilecek hapis cezası on beş yıldan az olamaz.”. Ancak bu ağır cezalara rağmen, Adalet Bakanlığı'nın Ocak 2016 verilerine göre Türkiye' de cezaevlerinde bulunanların \%18.9'u uyuşturucu madde suçlarından yatmaktadır( “Cezaevleri Alarm Veriyor", 2016). Bu durum ise tek başına ağır cezaların caydırıcılık yönünün sorgulanmasına sebep olmaktadır.

Bundan yola çıkarak da bu araştırmada ilk olarak uyuşturucu suçlularının uyuşturucu maddesine olan bakış açıları, ikinci olarak eski hükümlü olan bu kişilerin cezaların caydırıcılıkları konusundaki düşünceleri ve son olarak da bu kişilerin, suçlu kimliklerinden dolayı toplum tarafından nasıl damgalandıkları konusu analiz edilmeye çalışılmaktadır. 


\section{SOSYAL BİLIMLER VE UYUŞTURUCU SUÇLARI}

Uyuşturucu suçları birey ve toplum yaşamında önemli tahribat ve sorunlara yol açması nedeniyle başta sosyal bilimler olmak üzere birçok disiplin tarafından ele alınmıştır. Suç literatüründe konuyla ilgili önemli çalışmalar mevcuttur. Ancak, bu konuda yabanc1 literatürün Türkiye'ye oranla daha zengin olduğu söylenebilir. Konuya dair sosyal bilimler alanında yapılan önemli araştırmalara yakından bakmak, araştırmanın sonuçlarının anlaşılmasına katkı sunacaktır.

Kızmaz'a (2005, s. 57) göre, Türkiye'de yapılmış suç araştırmalarının sayısı oldukça sınırlıdır. Bazı suçlar için çok az, bazı suç türleri için de neredeyse hiçbir araştırmanın yapılmadığını söylemek mümkündür. Kızmaz'ın da belirttiği gibi sadece uyuş̧turucu konusunda değil, Türkiye'de suç literatüründe ciddi bir eksiklik söz konusudur. Uyuşturucu suçları ile ilgili yapılan araştırmaları değerlendirdiğimizde uyuşturucu suçlarının ikiye ayrıldığı görülmektedir: 1. Uyuşturucu madde kullanıcıları üzerine yapılan araştırmalar. 2. Uyuşturucu madde satıcıları üzerine yapılan araştırmalar. Dünyada ve Türkiye'de uyuşturucu madde kullanıcıları üzerine yapılan araştırmalar çok daha yaygındır. Uyuşturucu satıcıları konusunda yapılan araştırmalar ise görece daha sınırlıdır. Bu durumun başlıca sebebi uyuşturucu satıcılarına ulaşmanın ve mülakat yapmanın oldukça zor ve riskli olmasıdır.

Türkiye'de uyuşturucu suçları ile ilgili yapılan araştırmalarda suçlunun daha çok sosyo-ekonomik ve demografik özellikleri üzerinde durulmaktadırlar (Ünlü \& Demir, 2012; İçli, 1985; Karakaya, 2013). Ünlü \& Demir'in (2012) araştırmasına göre, sokaktaki uyuşturucu satıcılarının çoğu erkek, uyuşturucu bağımlısı, düşük eğitim seviyesine sahip, gelir seviyesi düşük ve yarısından fazlasının da geçmişte sabıka kaydı vardır. Ayrıca, bağımlı olmayan satıcılar uyuşturucu satıcılığını daha çok profesyonel bir meslek olarak görmektedirler. İçli (1985) ise 155 hükümlünün cezaevi kayıtlarının incelenmesiyle yaptığı araştırmada, \% 49’u okuryazar ve \%25'inin ilkokul mezunu olduğu görülen hükümlüler eğitim durumlarına bağlı olarak düzenli gelir getiren ve toplumda prestijli işlere sahip olmadıkları bulgusuna ulaşmıştır. Karakaya (2013) da yaptığ1 araştırmada Erzurum'daki uyuş̧turucu ticareti yapan beş organize suç örgütünü ve örgüt 
mensuplarının özelliklerini analiz etmiştir. Örgüt liderliğinin uyuşturucu madde teminine göre şekillendiği bilgisine ulaşmıştır.

Avrupa ve Amerika'da ise uyuşturucu satıcıları konusunda kapsamlı çalışmalar söz konusudur. Yapılan çalışmalar bu konular çerçevesinde sınıflandırılabilir: Uyuşturucu satıcılarının suçlu olma süreçleri (Adler, 1985; Bucerius, 2007; Sandberg, 2010), kişisel özellikleri (Sandberg, 2010; Jacques \& Wright, 2015; Bucerius, 2012), uyuşturucu ticareti ve toplumsal cinsiyet (Grundetjern \& Sandberg, 2012; Fleetwood, 2014) ve uyuşturucu satıcılarının toplum tarafından damgalanmaları (Bucerius, 2012; Sales \& Murphy, 2012). Adler'in (1985) çalışması uyuşturucu satıcıları ile ilgili yapılan ilk kapsamlı çalışma olmasından dolayı suç literatüründe önemli bir yeri vardır. Adler, uyuşturucu satıcılarının suçlu olma süreçlerini analiz ettiği çalışmasında, satıcıların sattıkları maddenin ekonomik değerine göre düşük ve yüksek dereceli uyuşturucu satıcılar olmak üzere ikiye ayırır. Ayrıca, kişilerin uyuşturucu dünyasına adım atmalarında güç ve prestij merakının önemini vurgular. Sandberg (2010), Norveç'de Müslüman kimliği; Bucerius (2012) Almanya'da yabancı (Türk, Afgan vb.) kimliği ile uyuşturucu ticareti arasındaki ilişkiyi analiz etmişlerdir. Grundetjern and Sandberg (2012) ve Fleetwood (2014) yaptıkları araştırmalarda uyuşturucu pazarının maskülen yapısını ve bu yapıda kadın uyuşturucu satıcılarının kendilerine nasıl yer açtıklarını incelemişlerdir. Bucerius ise (2012) Almanya'daki Müslüman uyuşturucu satıcıları üzerinde yaptığ 5 yıllık etnografik çalışmada, bu kişilerin çeşitli yollarla damgalama ve dışlanmayı deneyimlemeleri ve bunun sonucunda da toplumla uzun dönem pozitif bir ilişki yaşama şansı yakalayamadıklarını tespit etmiş̧ir. Bucerius, bu genç adamların sosyal, politik ve ekonomik dışlanmanın bir sonucu olarak uyuşturucu ticaretine nasıl dahil olduklarını gözlemlemiştir. Sales \& Murphy (2012) ise, San Francisco'daki uyuşturucu satıcılarıyla yaptıkları çalışmada, uyuşturucu satıcısı olmanın kişilerin damgalanmalarının derecesinde önemli bir role sahip olduğunu belirtmişlerdir. Bu çalışmalar hem suçlu bakış açısının araştırmaya dahil etmesi hem de uyuşturucu pazarı gibi girilmesi zor bir alana ışı tutması yönünden önemlidir. 


\section{TEORIK ÇERÇEVE}

Suç ve suçlu davranışını açıklayan teoriler içerisinde 20.yy’a kadar egemen olan düşünce, bireyin fizyolojik ve biyolojik özelliklerinin suçlu davranışında en önemli etken oluşuydu. Ancak 20.yy'da Sembolik Etkileşimcilik yaklaşımı ile birlikte (Özellikle Chicago Okulu) suçun nedenleri bireyin dışında da aranmaya başlanmıştır. $\mathrm{Bu}$ anlamda suçun bilimsel olarak değerlendirilmesinde bir paradigma değişikliği söz konusudur.

Sembolik etkileşimcilik toplumun mikro boyutlarına, gündelik yaşantılarımıza, içinde yaşadığımız gündelik dünyaya ve insanların "sembolik iletişim" aracılığıyla gündelik yaşantılarında nasıl etkileştiklerine, düzen ve anlamı nasıl yarattıklarına odaklanır. Klasik sosyologların kullandıkları bilimsel yaklaşımı reddeden bu sosyolojik perspektif, toplumu içerden analiz eder ve belirli bir durum veya yaşam biçimiyle ilgili insanları güdüleyen temel faktörleri görmeye çalışır (Slattery, 2008, s. 333-334). Sembolik etkileşimciliğin fikir babası olan Mead'e göre daha önce bir toplumsal grup olmadan düşünen, öz-bilinçli birey, mantıksal olarak olanaksızdır. Toplumsal grup, ilk sırada gelir ve öz-bilinçli zihinsel durumların gelişimine yol açar (Ritzer \& Stepnisky, 2014). Chicago Üniversitesi’nde Mead ile çalışan öğrencisi Blumer, aynı zamanda “sembolik etkileşimcilik” kavramını 1937 yılında ilk defa kullanan kişidir. Blumer’a göre, sembolik etkileşimcilik şu üç önermeye dayanır:

- İnsanlar şeylere karşı, şeylerin kendilerine ifade ettiği anlamlara göre tavır alırlar.

- $\quad$ Bu anlamlar, birinin muhataplarıyla olan etkileşimden çıkarsanır.

- Bu anlamlar yorumsal bir süreçte değişime uğrar (Polama, 1993, s. 224)

Sembolik Etkileşimcilerin suça bakış açıları 19. yy’dan beri hâkim olan Pozitivist bakış açısından farklıdır. Genel olarak Pozitivist yaklaşımda suçlu davranışı neden-sonuç ilişkisi üzerinden açıklanmaya çalışılmaktadır. Ancak Etkileşimci yaklaşımda bireylerin yorumlama, etkileşim, yansıma ve bilgi içerisinde 
anlamaya çalışılması gerektiği savunulur. Ayrıca Sembolikçiler, suçlu davranışla birlikte bireyin suçlu bir bireye dönüşme sürecine de önem atfederler.

Suç ve sapmayı birey ve toplum arasında cereyan eden dinamik ve aktif etkileşim sürecinin bir sonucu olarak gören Sembolik Etkileşim yaklaşımına göre kişilerin kendi benlik bilinci doğuştan gelen değişmez bir şey değildir. Bu yaklaşıma göre öz kimlik diğer insanlardan gelen yorumlardan, değerlendirmelerden ve her türlü geri bildirimlerden de yoğun bir şekilde etkilenir. Kriminoloji Literatüründe Damgalama perspektifi olarak ün kazanan teorik yaklaşım da suçu ve suçlu davranışı yoğun bir şekilde Sembolik Etkileşimin bir fonksiyonu olarak ele alır (Dolu, 2015, s. 444-445). Suç literatüründe damgalama teorisi içerisinde Tannenbum, Lemert, Goffman ve Becker'ın çalışmaları başı çekmektedir. Tannenbaum (1938) "Suç ve Toplum" adlı eserinde suçun bireysel davranışların sonucundan meydana gelmediğini, sosyal etkileşim sonucunda öğrenilen bir süreç olduğunu savunarak farklı bir bakış açısı getirmiştir. Lemert (1951)'a göre ise önemli olan suçun nedenleri değil, toplumun suçlu davranışa gösterdiği tepkiydi. Bu tepki, suçlu davranışın tekrarlanma olasılı̆̆ını etkileme özelliğine sahipti. Goffman (1963) damgalanmış bireyin öğrenme sürecinde iki aşama söz konusu olduğunu belirtir: Kişinin normal bakış açısını öğrenmesi ve bu bakış açısına göre kendisinin yetersiz olduğunu öğrenmesi. Muhtemelen sonraki aşama artık, ait olduğu kişi tipini idare etmeyi, diğerlerinin bu kişi tipine muamele tarzıyla nasıl başa çıkacağını öğrendiği aşamadır. Bundan sonraki aşama da yani aldatıcı görünüm sergilemeyi öğrenme aşamasının ele alındığı aşamadır. Becker'a göre ise bir kimsenin sabit bir suçlu kariyer geliştirmesinde en önemli aşama, yakalanması ve suçlu olarak damgalanmasıdır. Çünkü bu tecrübe sonucunda bireyin toplumun bir ferdi olarak sosyal faaliyetlere katılımı, benlik imajı ve sosyal kimliği ciddi zarar görür. Suçun kaç kez işlendiği artık önemli değildir; zira artık o bir suçludur (Becker, 1963, s. 31). Araştırmamız çerçevesinde alan araştırmasından elde edilen verileri bilimsel olarak analiz etmede en yetkin teorik çerçeve sembolik etkileşim ve damgalama kuramları olmasından dolayı söz edilen bakış açıları bir kılavuz niteliğinde kullanılmıştır. 


\section{ARAŞTIRMA YÖNTEMI}

Bu çalışma, Diyarbakır'da yaşayan uyuşturucu ticaretinden hapis yatmış 15 eski hükümlü ile yüz yüze derinlemesine mülakat içeren alan araştırmasına dayanmaktadır. 2015-2017 yılları arasında yapılan bu çalışmada uyuşturucu satıcıları olarak uyuşturucu kaçakçıları, uyuşturucu yetiştiricisi// üreticileri, uyuşturucu nakliyecileri ve torbacılar ile görüşülmüştür. Katılımcılar sattıkları uyuşturucu maddenin ekonomik değerine göre üst, orta ve alt seviye olarak ayrılmaktadırlar. Görüşmeye katılanların 15'i de erkektir. Katılımcıların hepsinin erkek olması uyuşturucu pazarının ve Diyarbakır bölgesinin maskülen yapısından kaynaklanmaktadır. Katılımcıların yaş ortalaması 42 olup bunun dağılımına baktığımızda, örneklemin \%33.3'ü 18-35, \%46.6'sinin 36-55 ve \%20'sinin ise 56 ve üstü yaşta oldukları görülmektedir.

Araştırmaya başlamadan önce Bilimsel Etik Kurul onay alınmıştır. Katılımcılara gönüllü katılım konusunda bilgilendirme yapılarak görüşmelere başlanmıştır. İlk katılımcıya tanıdık bir avukat aracılığıyla ulaşılıp o kişilerle belli bir güven ilişkisi edindikten sonra diğer katılımcılara kartopu tekniği kullanılarak ulaşılmıştır. Araştırmacının hemşerilik ilişkileri ve etnik kökeni yapılan görüşmelerde güven ilişkisini sağlamada kolaylaştırıcı etkiye neden olmuştur. Görüşmelerde yarı yapılandırılmış mülakat formu kullanılmış ve ses kaydı alınmıştır. Bu ses kayıtlarından elde edilen veriler kişilerin hangi tür uyuşturucu sattığına ve uyuşturucu ticaretindeki statülerine göre (Uluslararası eroin kaçakçısı, esrar eken, torbacı gibi) araştırmacı tarafından kodlanmıştır.

Damgalanma sürecini ve suçluların düşüncelerini daha derin kavrayabilmek için nitel araştırma yöntemi seçilmiştir. Nitel araştırmanın araştırmacıya sağladığı esneklik olanağı ve keşfedici yapısı bu araştırmada olduğu gibi az çalışılmış konularda kolaylık sağlamaktadır. Araştırma alanı olarak Diyarbakır ilinin seçilmesi, tarihsel süreç içerisinde uyuşturucu ticaretinde Diyarbakır'ın önemli bir yerinin olmasından kaynaklanmaktadır. Polis Akademisi Uluslararası Terörizm ve Sınır aşan Suçlar Araştırma Merkezi (UTSAM)'nin verilerine göre, Türkiye genelinde yapılan yasa dışı esrar ekiminin üçte ikisi Diyarbakır ilinde ve özellikle Lice ilçesinde yapılmaktadır (Utsam, 2013). 
Bu bağlamda Diyarbakır ilinde, eski hükümlü olmak üzere 15 uyuşturucu satıcısıyla yüz yüze yapılan derinlemesine mülakatlar ve gözlemleri içeren bu çalışmada, uyuşturucu satıcılarının uyuşturucu maddesine, uyuşturucu cezalarına ve toplum tarafindan damgalanmalarına olan bakış açıları analiz edilmeye çalışılmıştır.

\section{ARAŞTIRMADA ELDE EDİLEN BULGULARININ DEĞERLENDİRİLMESİ Uyuşturucu Maddesine Olan Bakış Açıları}

Suç alanında yapılan çalışmalarda suçlu bakış açısının önemi son zamanlarda kavranmaya başlanmıştır. Suç literatüründe genellikle suçlu bakış açısı göz ardı edilmektedir; ancak suç davranışının altında yatan nedenleri kavrayabilmek açısında suçlunun bakış açısı hayati derece de önem arz etmektedir. Toplumda genel olarak bulunan suçlularla ilgili kanılar gerçeklerle her zaman uyuşmayabilirler.

1950’lerde suçluların toplumun çoğunluğunu oluşturan orta sınıf değerlerinin tam tersi olan değerler taşıdıkları görüşü oldukça yaygındı ve bu görüşü “Suçlu Çocuklar” isimli eseriyle Albert Cohen temsil etmekteydi. Cohen (1955), suçlu alt kültürünün toplumun çoğunluğunun sahip olduğu değerlere taban tabana zıt ve kendilerine özel alternatif bir alt kültür oluşturduklarını iddia etmişti. Ne var ki, Sykes \& Matza (1957) Cohen'i bu görüşleri dolayısıyla eleştirmiş ve hatta bir adım ileri giderek aslında "suçluların da genel olarak suçlu davranışları onaylamadıklarını" iddia etmişlerdi. Aslında suçluların da toplumun geriye kalan diğer fertleriyle aynı kültürü paylaştıklarını ve benzer bir değerler sistemi içinde yaşadıklarını, ancak vicdanlarının sesini kısacak bir takım nötrleştirme teknikler uyguladıklarını düşünüyorlardı. (Cullen \& Agnew, 2003, s. 135'den aktaran Dolu, 2015, s. 263). Bu bölümde de katılımcılara araştırmacı tarafindan uyuşturucu madde ile ilgili düşünceleri sorulmuştur. Katılımcılardan elde edilen cevaplar Skyes \& Matza'nın görüşlerini doğrular niteliktedir. 
"Uyuşturucu kötü bir şeydir, ondan kötüsü yok. Yani uyuşturucuya bağlı bir insan, kendini insan zannetmiyor ki. İnsanlık dışına çıkan biri oluyor ha (Uyuşturucu Kaçakçısı/ Nakliyatçı, Eroin, 60 yaşında)."

"Ben diyorum hiç bir uyuşturucu kimyasal insanlarımıza satılmasın, yazıktır. Kimyasala karşıyım. Esrar bir ottur ama bu da bir başlangıçtır, zamanla insan daha güçlüsünü istiyor, eroin içiyor sonra kokaine düşüyor, daha sonra iğne kullanıyor, bunun sonu intihardır (Uyuşturucu Satıcısı, Eroin, 61 yaşında)."

"Uyuşturucunun iyi olmadığını düşünüyorum. Kesinlikle bunu kimsenin içmemesini ve yapmamasını tavsiye ediyorum. Ben mesela baya uğraştım ektim ama asla içmedim (Üretici/ Eken, Esrar, 31 yaşında).”

"Güzel bir soru sordun. Hiç kimseye tavsiye etmiyorum. Hele kimyasal... kimyasal derken. İçiyorsansa esrar içersin. Ne bir zararı var. Maddi olarak ha. Gidersin 20-30 tl verirsin içersin. Ne kimseye karışırsın, ne kimseyle işin olur. Ona para lazım değil. İçmezsen daha güzel olur (Torbacı, Esrar, 37).”

Katılımcıların cevaplarını değerlendirdiğimizde, uyuşturucu satıcılarının toplumun çoğunluğunun sahip olduğu değerlere taban tabana zıt değerlere sahip olmadığı görülmektedir. Toplumun genelindeki kanının aksine, aslında onlarda aynı değerlere sahiptir ancak yaptıkları işi bir tür ticaret ve para kazanma kaynağı olarak görmektedirler. Bu işi yaparken de vicdanen rahatlamak için belli stratejiler kullanmaktadırlar. Bu noktada Skyze \& Matza beş çeşit nötrleştirme tekniğinden bahsetmektedir: 1. Sorumluluğun reddedilmesi 2. Zararın reddedilmesi 3. Mağdurun varlığının reddedilmesi 4. Kendilerini lanetleyenlerin lanetlenmesi ve 5. Kendi değerlerini toplumun değerlerinden üstün görme (Sykes \& Matza, 1957, s. 665-666). Bu araştırmada da, katılımcılar uyuşturucu konusunda düşüncelerini açıklarken Skyze \& Matza’nın belirttikleri nötrleştirme tekniklerini kullandıkları dikkat çekmektedir: 
“Şimdi mesela seksenlerde, genelde buradan Avrupa'ya gitme şeyiyle yapılmış. Orada ne şekilde yapılmış kimse bilmez, hani bizim yaptığımız sadece ticaret gibi olmuş. Yani insanlar o dönem hani bunu eroini içenlerin hayatı kararıyor, sonunda ölüm var gibi şeyleri bilmiyorduk. Şimdi içme yaşı 13-14 e düşmüş, hani tasvip edilecek bir şey değil (Uyuşturucu Kaçakçısı, Eroin, 74).”

"Uyuşturucu hakkında ne düşünüyorum? Genelleme yaparsak, ne iyidir, ne kötüdür. Ben inandığımı söylüyorum, gerçekten de samimiyim. Kokain halen Güney Amerika'da doğal olarak madde karışımı olmadan kimyasal girmeden, yerli halk yaprağını sakız gibi ağzına atıp çiğniyor, ağr1 gidericidir, yorgunluk gidericidir. Problem nerededir? Problem şudur: \% 80lik bir eroini alıyorlar, bir kilosuna 7 kiloluk katkı koyuyorlar. Koyulan katkı hepsi kimyasal maddedir. Bu maddeler öldürücü maddelerdir, insanlar üzerinde yaralar yapıyor. Kimyasal çok facia bir şeydir... Neden? Fazla para kazanmak için. İnsanlar plastik içiyor. Ama haberleri yok. İçtiği bir gram kokainin yüzde 60-70’i kimyasal maddedir. İnsanlar üzerinde en çok etki eden insanın fizyolojisini değiştiren, beynini değiştiren, hasta eden, kimyasını bozan kimyasallardır (Uluslararası Uyuşturucu Kaçakçısı, Kokain/ Eroin, 52 yaşında).”

"Uyuşturucuların hepsi bir değildir mesela. Kimyasal olan şeylere karşıyım mesela. Kokain, eroin içen insanlara karşıyım. Esrar dediğin zaman ottur, topraktan gelen bir şeydir. Kimi diyor ottur günahı yoktur hesabı. Sana zararı vardır bir tek. Mesela bugüne kadar bir insanı öldürdüğünü görmedim. Bugün toplumun \% 40 - \%50'si bu maddeyi içiyordur. O kadar kötü bir etkisi yok (Torbac1, Esrar, 27).”

Araştırma bulgularında, katılımcıların kullandıkları nötrleştirme teknikleri şunlardır: "Sonunda ölüm var gibi şeyleri bilmiyorduk" (Sorumluluğun reddedilmesi), "Esrar dediğin zaman ottur, topraktan gelen bir şeydir. Mesela bugüne kadar bir insanı öldürdügünü görmedim” (Mağdurun varlığının reddedilmesi), “Kokain halen Güney Amerika'da doğal olarak madde karışımı olmadan kimyasal girmeden, yerli halk yaprağını sakız gibi ağzına atıp çiğniyor, ağrı gidericidir, yorgunluk gidericidir.” (Zararın reddedilmesi) 
gibi. Katılımcıların kullandıkları nötrleştirme teknikleri, yaptıkları işi meşrulaştırmalarında etkili olduğu gözlemlenmektedir.

\section{Uyuşturucu Madde Kullanım Alışkanlıkları}

Bu bölümde, katılımcılara uyuşturucu madde kullanım alışkanlıkları sorulmuştur. Katılımcıların verdikleri cevaplar uyuşturucu pazarındaki hiyerarşik düzende bulundukları statülerine göre değişmektedir. Öncelikle şunu açıklamak gerekmektedir: Araştırma bulgularımıza göre uyuşturucu pazarında, uyuşturucu satıcılarının oluşturdukları hiyerarşik bir düzen söz konusudur. Bu hiyerarşik düzen içerisinde en üst aşamada uluslararası kaçakçılar (Eroin/ Kokain), sırasıyla Türkiye'de dağıtımı yapan uyuşturucu kaçakçıları (Eroin/ Kokain), esrar ekenler, esrar satıcıları, nakliyatçılar, hap satıcıları ve torbacılar gelmektedir. $\mathrm{Bu}$ hiyerarşik düzeni belirleyen, satıcıların sattıkları uyuşturucu maddenin türü ve bu maddenin ekonomik değeridir. Uluslararası uyuşturucu kaçakçıları büyük servetler kazanırken, torbacılar ancak günü kurtarabilmektedirler. Bu ekonomik düzeydeki farklılıklar uyuşturucu satıcılarının günlük davranış pratiklerinde de önemli farklılıklar yaratmaktadırlar. Bunlardan biri de uyuşturucu madde kullanımı alışkanlıklarıdır:

“Özel olarak uyuşturucu hiç kullanmadım. Ama yaptığım bütün işlerde kendim tahlil etmişimdir.

Bütün maddeleri eroin, kokain, onların dışında hiçbir uyuşturucuyla uğraşmadım (Uluslararası Uyuşturucu Kaçakçısı, Kokain, 52 yaşında).”

"Yok, hiç kullanmadım (Uyuşturucu Kaçakçısı, Eroin, 58)."

"Ben hayatımda hiç uyuşturucu kullanmadım, 21 sene sigara içtim, cezaevinde sigarayı da bıraktım (Uyuşturucu Kaçakçısı, Eroin, 46 yaşında)."

"Hayatımda hiç içmedim, ne esrar, ne eroin, ne rakı, ne bira, ne viski emin ol boğazımdan aşağı geçmemiştir. (Kimyasal işini siz yapmıyor muydunuz?) Ya yapıyorduk, ama dört beş kişi beraber. 
Hem onu yapanlar genelde kullanmaz. Hem de kullanan kişileri yapmaya götürmezler, kullanıyorsa yaparken çalabilir, böylelikle de yakalanır (Uyuşturucu Kaçakçısı, Eroin, 74 yaşında).”

Katılımcıların uyuşturucu madde kullanım davranışlarına baktığımızda, hiyerarşik anlamda üst seviyelerde olan uyuşturucu kaçakçılarında uyuşturucu madde kullanımının az olduğunu ya da hiç olmadığını görebiliyoruz. Ancak daha alt kesimlerde olan esrar eken, esrar satıcıları, nakliyatçılar ve torbacılar arasında uyuşturucu madde kullanımının sıklığg göze çarpmaktadır.

“18 yaşımda ben esrara başladım. 20 yaşında esrarı bıraktım. Baktım öleceğim, kupkuru kalmıştım (Gülüşmeler). Bir silkelendim (Nakliyatçı, Esrar, 55).”

“Tabi tabi. Toplasan 7-8 sene vardır. Tabi ben kısa söylüyorum daha fazla da vardır (Torbacı, Esrar, 27)."

"Benim içmediğim madde yoktu: kokain, hap, esrar, alkol... Şimdi hiçbirini kullanmıyorum. Hiçbirini... boş sigara bile kullanmıyorum (Torbacı, 37).”

Uyuşturucu kullanımının uyuşturucu satıcıları arasında hiyerarşik düzeyde yarattığı bu farklılıkların temelinde uyuşturucu pazarına 1şı tutan önemli bilgiler bulunmaktadır. Katılımcılardan elde edilen bulgulara göre, uyuşturucu pazarı çok büyük miktarlarda sermayenin döndüğü ancak illegal yapısından dolayı sadece kişiler arasındaki güven üzerine kurulu ilişkiler ağlarıdır. Bu kişilerin yapacakları bir hata çok büyük bir sermaye kaybına bunun yanı sıra senelerce hapishanede yatmalarına sebep olabilmektedir. Bu nedenden dolayı, özellikle üst seviyedeki uyuşturucu satıcıları "iş" yaptıkları kişilerde belli kriterler aramaktadırlar: Kişilerin güvenilir olması, sözüne sadık olması ve bunları yapabilmesi içinde her şeyden önce uyuşturucu madde bağımlısı olmamasıdır. Üst seviyelerde bulunan uyuşturucu kaçakçılarının uyuşturucu bağımlısı olmamalarının ve bu konuya özellikle önem vermelerinin sebebi bu güven ilişkisi içerisinde güvensizliğe sebep olmamaktır. Uyuşturucu madde kullanımı da kendi içerisinde ciddi bir güven eksikliğine sebep olduğu için camia içerisinde önemli bir "prestij kaybı” olarak sayılmaktadır. 


\section{Cezalar Caydırıcı mi?}

Cezaların suç literatüründe önemli bir yeri bulunmaktadır. Suç eylemine yönelik olarak öngörülen/uygulanan cezanın işlevi genel olarak iki temel gerekçe ekseninde tartışılmaktadır: 1. Suçlunun işlediği suçtan dolayı cezalandırmayı hak ettiği ve bu nedenle cezalandırılması gerektiğini ileri süren yaklaşım. Bu yaklaşıma göre kriminal yaptırımın amacı, suçludan intikam veya öç almaktır. 2. cezanın amacı, bireyi suç işlemekten vazgeçirmek veya caydırmaktır. Bu yaklaşımın amacı ise; suçu önleme, suçluyu 1slah etme ve onu yeniden topluma kazandırmaktır (Reid, 1982, s. 472 aktaran İçli \& Öğün, 1999, s. 35). Cezaların suçlu davranışını ve suçun tekerrür etmesini önlemede rolü yadsınamaz. Ancak ağır cezaların her zaman etkili olduğunu söylemek mümkün değildir. Bu bölümde de katılımcılara uyuşturucu suçlarına verilen cezaların caydırıcılıkları konusundaki görüşleri sorulmuştur:

"Caydırıcı, cezalar az değil. Ben atıyorum 40 yaşımda içeri girsem, 20 yıl yatsam zaten ölünce çıkıyorum. Bir insan beyinde bırakması lazım. Yani kötü şeyleri beyinde bırakmak lazım. Böyle cezayla mezayla bu işler yürümez. Okumak lazım. Hayatı görmek lazım. Ben okumamışım, sen burada anlat, ben çıkınca suç işlerim (Uyuşturucu Nakliyatçısı, Eroin, 60).”

"Caydırıcı değil. Yüz sene de versen bir adam yapsa yapar yine. Kesinlikle caydırıcı bir ceza yoktur (Uyuşturucu Kaçakçıs1, Eroin, 46).”

“Zaten caydırmış beni. Çıktım yapmıyorum (Uyuşturucu Kaçakçısı, Eroin, 58).”

Katılımcılardan elde edilen bulgulara göre, uyuşturucu satıcılarının büyük bir kısmı, tek başına ağır cezaların yeterli olmadığını, çıktıktan sonra aynı şartlara sahip ise suçun tekerrür edebileceğini ifade ederken bir kısım uyuşturucu satıcıları ise uzun yıllar hapiste kalmanın caydırıcı olduğunu belirtmişlerdir. Lerner \& Lerner (2006)'a göre, hapse girdikten sonra belli bir grubun fikirleri değişmekte ve kendilerini aslında kanunlara saygılı bireyler olarak ifade etmeye başlamaktadırlar. Hapiste olmalarının nedenini ise yanlış zamanda yanlış yerde olmak şeklinde izah etmeye çalıştıkları ve dışarı çıktıkları zaman hiçbir şeyin 
eskisi gibi olmayacağını ifade ettikleri bilinmektedir. Başka bir grubun ise acemi bir suçlu olarak girdikleri hapishanelerden, kıdemli suçluların gözetmenliğinde daha karmaşı suçları işleyebilecek kapasiteye ulaştıkları bir eğitim sürecinden geçtikleri ve çıtıklarında da adeta usta bir kariyer suçlusu olarak hayatlarına devam ettikleri görülmektedir (Lerner \& Lerner, 2006, s. 3'den aktaran Dolu, 2015, s. 103).

Sherman (1993) da kişinin aldığı cezayı haksız bulması durumunda kişide direnç oluşacağını ve dolayısıyla da suçtan caymak yerine yeniden suç işleme yolunda daha da bileneceğini ifade etmektedir. Önemle durulması gereken bir diğer nokta ise, hapishanelerin cezaların caydırıcılığı işlevinin yanı sıra, bazı suçlular için acemi olarak girdikleri hapishanelerde profesyonel suçlulara dönüşmelerinde bir tür okul görevi görmeleridir.

"Yahu caydırıcı diyorsak da, hapisten sonra bazı insanlar açılıyor daha da hızlı oluyor. Öğreniyor, alışverişi öğreniyor, aynı zamanda insan daha da hırslanıyor. Yattığım yılların acısını çıkartayım diyor. Yani o yüksek cezalar caydırıcı değil ha. Ama hapisten sonra bence daha da artar (Uyuşturucu Kaçakçısı, Eroin, 46).”

“İnan değil. Yani adam belki bilinçsizce ihtiyacından dolayı yapmıştır veya kullanmıştır. Hani mesela borcu vardır, krediyle ev almıştır, parasını ödeyemiyordur. İşte adam köşeye sıkışınca yapıyor bu işi, ama yakalanınca pişman oluyor işte diyor ben ne yaptım, ailem gitti, çoluğumçocuğum gitti, hayatım gitti. Zaten param yoktu ki, bu işe başladım peki şimdi ne olacak diyor. Ama hapiste cezadan ders almak yerine, gidiyor orada herkesi tanıyor, satıcısından ekicisine kadar çevresini genişletiyor, çıktıktan sonra da profesyonel oluyor (Hap Satıcısı, 42).”

Ayrıca, Becker (1963) uyuşturucu ticaretinde hapishanelerin bir başka önemli rolüne işaret eder. Becker'a göre uyuşturucu satıcılarının yakalanması ve hapse atılması, toplumun uyuşturucu kullanımı üzerindeki yasal yaptırımlarını dolaylı olarak yansıtır. Yasanın uygulanması doğrudan kullananları yakalayarak değil, uyuşturucunun kaynaklarını istikrarsız kılarak ve erişimi daha zorlaştırarak kullanımı denetim altına almaya 
çalışır. Dolayısıyla her bir kullanım düzeyinin başlangıçtan rutinleşmiş kullanıma kadar, kendine özgü bir arz tipi vardır ve söz konusu kullanımın devam etmesi için bu arz tipi varlığını sürdürmelidir (Becker, 1963, s. 95). Becker'ın da belirttiği gibi, uyuşturucu satıcılarının yakalanıp hapiste tutulması uyuşturucu arzını azaltması yönünden önemli bir etkiye sahiptir. Ayrıca ağır cezaların olması bir yere kadar insanları korkutup caydırma özelliğine de sahiptir. Ancak son yıllardaki uyuşturucu suç oranları ve cezaların mükerrerliğine baktığımızda cezaların suçu önleme, ıslah etme ve kişileri yeniden topluma kazandırma işlevleri tartışmaya açıktır. Bu araştırmada da üzerinde durulmaya çalışılan nokta tek başına verilen ağır hapis cezalarının yeterli olmadığıdır.

\section{Toplum Tarafindan Damgalaniyorlar mi?}

Uyuşturucu satıcılarının yaşamlarında en önemli süreçlerden biri bir suçlu olarak yakalanıp hapiste yattıktan sonra toplum tarafından damgalanmalarıdır. Kişilerin yaşadıkları bu süreç hapishane sonrası hayatlarına "normal" bir kişi olarak mı yoksa tekrar "suçlu" statüsünde mi döneceklerini etkileme gücüne sahiptir. Becker'a (1963, s. 56) göre, istikrarlı bir suçlu davranış örüntüsü inşa etme sürecindeki çok önemli evrelerden biri, yakalanma ve kamusal olarak sapkın etiketini yeme deneyimi olabilir. Önemli olan, kişinin bu evrede ne yapacağından ziyade diğerleri tarafından ne yapılacağı, çiğnenen kuralın karşılı̆̆ olan yaptırımın kişiye uygulanıp uygulanmayacağıdır. Goffman (1963)'a göre ise bu sosyalleşme sürecinin ilk safhası, damgalı bireyin normallerin bakış açısını öğrendiği ve içselleştirdiği safhadır. Aynı zamanda bu safha, damgalı bireyin toplumun kendisine sunduğu benlik imgelerini edindiği ve böyle bir damgaya sahip olmanın nasıl bir şey olduğunu kavramaya başladığı evredir. Bunu takip eden diğer safha ise, bu damgaya sahip olduğunu artık iyice öğrendiği ve ona sahip olmanın beraberinde getirdiği sonuçları bu kez ayrıntılı biçimde ve netlikle kavradığı safhadır (Goffman, 1963, s. 66). Bu bölümde katılımcılara, hapishaneden çıktıktan sonra toplum tarafindan suçlu kimliklerinden dolayı herhangi bir damgalanma/ etiketlenme yaşayıp yaşamadıkları sorulmuştur:

$\mathrm{SAD} / \mathrm{JSR}$

Cilt / Volume 20 Sayı / Number 2 
“Ya keşke eski hayatıma dönebilsem. Eski işime...1996' da ehliyetimi aldım, abla. Benim şu anda gençlerin yaşı kadar ehliyetim var. Ben çekirdekten yetişmeyim. Üstüme de araba kullananı tanımam. Ama gel gelelim bu illete düşmüşüz. Bir türlü yakamızı bırakmıyor. Biz bırakıyoruz, o bırakmıyor bizi. Yoksa ben nereye gitsem çalışırım. İstanbul'a, burada Dağkapı'da. Beni tanımayan yok bu iş için ha. Şimdi adam korkuyor. Diyor getirsem yine bu işi yapar mı? Arabamda uyuşturucu satar mı? Haklı olarak. İsmin çıkmış dokuza inmiyor sekize. Nasıl yapacaksan abla? (Uyuşturucu Satıc1s1, Esrar, 37)."

"Tabii, yani böyle bir yere gidiyorum oturuyorum, yanımdaki adam korkuyor benden kaçıyor... Ben şu anda otuz senedir tanıdığım adamlar benden kaçıyor yani. Ben ne yapabilirim, yani canın sağ olsun diyorum, ne diyim (Uyuşturucu Kaçakçıs1, 46).”

"Vallahi ben kendim nasıl deyim bu işi yaptığımı gizlemeye çalışıyorum, sabıkamın olduğunu gizliyorum, ama uyuşturucu dedin mi, her şey bitiyor. Narkotik olayı biraz itici geliyor anladın mı? Kendi çevrenden gelen tepki, şöyledir mesela, derler ya işte sana yakıştırmadım ha (Hap Satıcısı, 42)."

"Tabi tabi. Çok iyi arkadaşlarımız var mesela. Bizimle kendi telefonlarıyla bile görüşmek istemiyorlar (Torbac1, 37)."

Katılımcılardan elde edilen bulgular, hapishaneden çıktıktan sonra eski suçluların toplum tarafından damgalandıklarını doğrulamaktadır. Kişilerin suçlu olarak damgalanmaları durumunda ise hem kişi için hem de toplum için belli sonuçları söz konusudur. Becker'a (1963, s. 56-57) göre kişinin suçlu olarak etiketlenmesinin toplumsal katılımı ve benlik imgesi açısından çok önemli sonuçları vardır. En önemli sonuç, kişinin kamusal kimliğindeki çarpıcı değişimdir. Uygunsuz davranışta bulunmak ve bunu yaparken yakalanmış olmak kişiyi yeni bir statüye yerleştirir.

$\mathrm{SAD} / \mathrm{JSR}$

Cilt / Volume 20 Say1 / Number 2 
Suçlular damgalanmalarından dolayı yaşadıkları gerilimi azaltmak için de toplumda belli stratejiler geliştirirler. Goffman'a (1963, s. 148) göre kişinin amacı; gerilimi azaltmak, yani damgasına yönelik örtük bir dikkatten kaçınmayı, hem kendisi hem de başkaları için kolaylaştırmak ve etkileşimin resmî içeriğine doğaçlama bir katılımı korumaktır. Katılımcı, yaşadığı damgalanmadan dolayı çevresine geliştirdiği stratejiyi şöyle açıklamaktadır:

"Yani karşındakinin hissine bağlı ve tavrı, hareketlerine bağlı olan bir şeydir. Mesela biz oturuyoruz dört kişi, sıra bana geldiyse diyorum ben ticareti yapıyordum. Yattım, çıktım. Adamın yüz rengine, bakış açısına, yüz mimiklerine bile dikkat edersin. Bakarsın rahatsız olduysa fazla şey yapmazsın, diyalog kurmazsın. Belli bir seviyede bırakırsın. Ama ne olur bir daha ki sefere onla görüşmezsin. Çünkü ne olur? Hem sen rahatsız olursun hem o rahatsız olur (Ekici, Esrar 27).”

Öte yandan, katılımcılar arasında damgalanmadıklarını düşünenler de söz konusudur. Bu kişiler de bulundukları sosyal grup içerisinde farklı sosyal normların varlığından dolayı toplumun genelinden farklı tepkiler almaktadırlar. Genel olanın aksine, çevreleri tarafından yaptıkları iş nedeniyle daha itibarlı olmaları söz konusudur.

“Açık konuşayım, etrafin daha kalabalıklaşıyor. Niye? Paran var diye, mal var diye, araban var diye, şeklin var diye. Millet sana saygı gösteriyor. Mahalleden giriyorsun herkes sana abi diyor. Ne için? Ona verdiğin biraz para için, yedirdiğin yemek için, gezdirdiğin için, açtırdığın bir içki masası için, ona verdiğin iki cigara için. Daha değerli oluyorsun toplumun gözünde (Torbacı, Esrar, 27).”

Bunun nedenini Shaw \& McKay (2003, s. 106) şöyle açıklamaktadır: Aynı anda hem yokluktan üstü baş1 perişan bir hayat yaşayanlarla son model arabalarıyla cepleri para dolu çete mensupları aynı caddelerde dolaşıyorlardı. Son derece lüks sayılabilecek imkâna sahip çete elemanlarının bunları nasıl elde ettiği, hangi köşede hangi riskleri göğüsleyerek bu imkânlara sahip olduğu sokaktaki insanlara görünmüyordu. Katılımcılardan elde edilen bilgilerden de anlaşılacağı gibi, bazı uyuşturucu satıcıları kendi sosyal grupları 
içerisinde kısmen itibar da görebilmektedir. Ancak bu durum, kişinin ekonomik refah seviyesine ve bu refah seviyesini çevresine aktarmasıyla doğru orantılıdır.

Uyuşturucu satıcılarının damgalanma konusunda değerlendirmelerini göz önüne aldığımızda, uyuşturucu satıcılarının suçlu kimliklerinden dolayı belirli bir düzeyde toplum tarafından olumsuz tepki almaları suçun tekerrür etmemesi ve toplumun oluşturduğu sosyal kontrol açısından olumlu olarak nitelendirilebilir. Ancak bu kişilerin hapishaneden çıktıktan sonra normal hayatlarına dönebilmeleri ve legal bir iş bulup geçimlerini sağlayabilmeleri suçun tekrarlanmaması açısından önemli bir yere sahiptir. Eğer kişilerin suç geçmişleri toplum tarafindan damgalanıp yasal bir iş bulmalarında engel teşkil ederse suçun tekerrür etme ihtimali de yükselir. Ayrıca, bu kişiler bulundukları sosyal grup içerisinde damgalanıp ötekileştirilmesi durumunda yanlarında kendini daha rahat hissettikleri diğer suçlularla görüşme eğiliminde olurlar. Bunun sonucunda da kişilerin tekrar uyuşturucu pazarına dönmeleri kaçııılmaz hale gelir. 


\section{SONUÇ}

Günümüzde uyuşturucu ticareti, bütün ülkeleri ilgilendiren ve her geçen günde artış gösteren geniş çaplı, küresel bir sosyal bir problemdir. Yasadışı uyuşturucu pazarlarından elde edilen yüksek miktarda paralar birçok toplumsal, siyasal ve ekonomik sorunlarında gelir kaynağını oluşturmaktadır. Bunların başında terör, diğer suç faaliyetleri, devlet kurumlarındaki yolsuzluklar, ekonomik ve toplumsal sorunlar gelmektedir. Dolayısıyla uyuşturucu ticareti sadece uyuşturucu satıcıları ve kullanıcılarına indirgenemeyecek kadar kapsamlı ve çok boyutlu bir sorunsaldır. Bu çalışmada, uyuşturucu pazarının ana unsurlarından biri olan uyuşturucu satıcılarının, suça olan bakış açıları, cezaların caydırıcılıkları konusundaki düşünceleri ve bir suçlu olarak toplum tarafından nasıl damgalandıkları analiz edilmeye çalışılmıştır. Bu anlamda bu kişilerin görüşlerinin alınması konuya farklı bir bakış açısı kazandırmıştır.

Uyuşturucu satıcıları ile yapılan görüşmelerden elde edilen verilere göre, ilk olarak uyuşturucu satıcılarının uyuşturucu madde ile ilgili toplumdaki diğer kişiler gibi olumsuz düşüncelere sahip oldukları görülmektedir, özellikle de kimyasal olarak nitelendirilen eroin, kokain, hap gibi uyuşturucu maddeler için. Uyuşturucu maddesine bu kadar olumsuz yaklaşmalarına rağmen ticaretini yapıyor olmalarının altında yatan sebep ise tümüyle bunu bir tür "bir tür ticaret" ya da "para kazanılan bir iş" olarak ele almalarından kaynaklanmaktadır. İkinci olarak, uyuşturucu madde kullanım alışkanlıkları ise satıcıların içinde bulundukları hiyerarşik düzeyde farklılıklar bulundurur. Üst düzeyde olan uyuşturucu kaçakçıları uyuşturucu madde hemen hemen hiç kullanmaz iken, daha alt seviyede olan uyuşturucu satıcıları arasında uyuşturucu madde özellikle esrar yaygındır. Üst seviyede olan kaçakçıların uyuşturucu kullanması milyon dolarların söz konusu olduğu uyuşturucu pazarlarında bağımlı olan bir kişiye güvenilmeyeceğinden dolayı "kariyerinin" bitmesine sebep olabilmektedir.

Üçüncü olarak da uyuşturucu satıcılarında genel olarak tek başına cezaların caydırıcı olmadığ görüşü yaygındır. Burada önemli noktalardan biri, uyuşturucu satıcılarına göre kişinin içinde bulunduğu sosyoekonomik durum cezaların caydırıcılığını azaltmaktadır. Cezalar ne kadar ağır olursa olsun, bu kişiler eğer 
maddi anlamda başka bir çıkar yol bulamıyorsa bu yolu seçmektedirler. Burada önemli bir konu da, suçluların acemi olarak girdikleri hapishanelerden tam bir profesyonel suçlu olarak çıkmalarıdır. Suçluların hapishanelerde kendileri ile aynı suçtan hüküm giyenlerle aynı koğuşlarda kalmaları ve bu sosyal etkileşim içerisinde bu kişilerin uyuşturucu ticaretinin bütün detaylarını öğrenip, uyuşturucu pazarındaki üreticisinden, satıcısına ve torbacısına kadar her türlü kademesini tanımaları buna sebep olmaktadır. Son olarak da, uyuşturucu satıcılarının suçlu olmalarından dolayı toplum tarafından damgalandıkları görülmektedir. Bu damgalanma süreci kişilerin günlük hayatını etkilediği gibi yeni bir hayata başlaması için gerekli olan yasal bir iş bulma sürecini de etkilemektedir. Bu durum, kişinin suçlu olarak damgalanmasından başlayarak bireyi suç davranışına zorlayan damgalanma döngüsüne sebep olabilmesi yönünden önemlidir.

Genel olarak değerlendirdiğimizde, uyuşturucu ticareti sadece adli cezalarla önlenemeyecek kadar kapsamlı ve geniş bir konudur. Suç davranışını önlemek amaçlı yapılan çalışmalarda suçlu bakış açısının değerlendirmeye alınması sorunun çözümünü kolaylaştıracağı düşünülmektedir. Uyuşturucu ticareti ile ilgili yapılacak araştırmalarda da uyuşturucu satıcılarının bakış açılarının da göz önüne alınması çalışmaların daha verimli ve etkili olması nedeniyle tavsiye edilmektedir. Bu suçların altında yatan sosyolojik nedenlerin çözümlenip farklı uygulamalara geçilmesi önem arz etmektedir. Ancak bu uygulamalar, başka bir araştırma konusu olacak kadar geniştir. 


\section{SUMMARY}

Nowadays drug trade is a global social problem that concerns all countries and increases each passing day. High amounts of money from illicit drug markets constitute a source of income for many social, political and economic problems. These include Terrorism, other criminal activities, corruption in state institutions, economic and social problems. Therefore, the drug trade is so comprehensive and multidimensional problem that cannot be reduced only to drug sellers and users.

In this research, drug dealers', one of the main elements of the drug market, perspectives on the drug, thoughts on deterrence of punishment and how they are seen by society as a criminal have been tried to be analyzed. In this sense, interviewing these persons has given a different perspective on to the issue.

Findings in this research are:

- Contrary to what is believed, it is seen that drug sellers generally have a very negative thought towards drug substances.

- Drug addiction of top-notch smugglers can cause their "career" to end because an addicted person cannot be trusted in drug markets where millions of dollars are concerned.

- From drug dealers' view, the punishments are not deterrent. Criminals come out of prisons as professional criminals that they entered as novices.

- Drug dealers are stigmatized by society because of their criminality. In the long term, the stigmatization increases the likelihood of repetition of their criminal behavior.

As a result, the drug trade is so comprehensive and wide that it cannot be prevented only by judicial punishments. It is important that the sociological reasons underlying these crimes are resolved and applied 
to different applications. It is also recommended to take the point of view of drug dealers in consideration on the drug trade because of the studies are more efficient and effective. 


\section{KAYNAKÇA}

Adler, P. A. (1985). Wheeling and Dealing: An Ethnography of An Upper-Level Dealing and Smuggling Community. New York: Colombia University Press.

Avrupa Uyuşturucu ve Uyuşturucu Bağımlılığı İzleme Merkezi (2016). Avrupa Uyuşturucu RaporuTrenler ve Gelişmeler, Lüksemburg: Avrupa Toplulukları Resmi Yayınlar Bürosu.

Becker, H. (1963). Hariciler (Outsiders) - Bir Sapkınlık Sosyolojisi Çalışması. Ş. Geniş, L. Ünsaldı (Çev.). Ankara: Heretik Yayıncılık.

Bucerius, M. S. (2007). What Should I do? Cultural Influences on The Drug Trade of Migrants in Germany. The Journal of Drug Issues, ss. 673-697.

Bucerius, S. (2012). What Do You Expect? That We All Dance and Be Happy? Second Generation Immigrants and Germany's 1999 Citizenship Reform. German Politics and Society, Issue 101, Vol: 30, Spring, ss. 71-85.

Cezaevleri Alarm Veriyor: Son 10 yılda tutuklu ve Hükümlü Sayıs1 117,7 arttı. (2016, Aralık 5). www.cumhuriyet.com.tr.

Cohen, A. (1955). Delinquent Boys: The Culture of Gang. Free Press.

Dolu, O. (2015). Suç Teorileri: Teori, Araştırma ve Uygulamada Kriminoloji. Ankara: Global Politika ve Strateji Yayınevi.

EMCDDA Yıllık Raporu (2007). Bağımlılık Yapıcı Maddeler ve Bağımlılık İle Mücadele Türkiye Raporu. Ankara: TUBİM.

European Monitoring Centre for Drugs and Drug Addiction (2016). EU Drug Market Reports, In-depth Analysis. Luxembourg: Publications Office of the European Union.

Fleetwood, J. (2014). Keeping Out of Trouble: Female Crack Cocaine Dealers in England. European Journal of Criminology, 11(1), pp. 91-109.

Jacques, S. \& Wright R. (2015). Code of the Suburb: Inside the World of Young Middle-Class Drug Dealers. Chicago: University Of Chicago Press, pp. 1656-1659. 
Grundetjern, H. \& Sandberg, S. (2012). Dealing with a Gendered Economy: Female Drug Dealers and Street Capital. European Journal of Criminology. 9(6), pp. 621 -635.

Goffman, E. (1963). Damga: Örselenmiş Kimliğin İdare Edilişi Üzerine Notlar. Ş. Geniş, L. Ünsaldı, S.N. Ağırnaslı (Çev.). Ankara: Heretik Yayıncılık.

İçli, T. (1985). Uyuşturucu Madde Suçlarında Bazı Sosyal Faktörler. Hacettepe Edebiyat Fakültesi Dergisi, 3(2), ss. 115-127.

İçli, T. ve Öğün, A. (1999). Türkiye'de Cezaevlerindeki Rehabilitasyon Faaliyetleriyle İlgili Sosyolojik Bir Analiz. Ankara: T. C. Adalet Bakanlığı Yarı Açık Cezaevi Matbaası.

Karakaya, M. (2013). Erzurum'daki Uyuşturucu Ticaretinin Analizi: Suç Şüphelileri, Suç Yapıları ve Suç Olayları. Uluslararası Sosyal Araştırmalar Dergisi. Cilt: 7, Sayı: 33, ss. 557-569.

Kızmaz, Z. (2005). Cezaevi Müdavimleri: İnatçı Suçlular. Ankara: Orion Kitabevi.

Lemert, E. (1951). Social Pathology: A Systematic Approach to the Theory of Sociopathic Behavior. New York: McGraw- Hill Book Company.

Resmi Gazete (2014). 5237 sayıl Türk Ceza Kanunu. 03 Ocak 2017 tarihinde www. Cezabb.adalet.gov.tr/mevzuat/5237.htm. adresinden alınmıştır.

Polama, M. M. (1993). Çağdaş Sosyoloji Kuramları. H. Erbaş (Çev.). Ankara: Gündoğan Yayınevi.

Ritzer, G. ve Stepnishky, J. (2014). Sosyoloji Kuramları. H. Hülür (Çev.), Ankara: De Ki Yayınevi.

Sandberg, S. (2010). The Sweet Taste of Sin- A Muslim Drug Dealer in a Nordic Welfare State. Journal of Scandinavian Studies in Criminology and Crime Prevention,11, pp. 103-118.

Sandberg, S. \& Grundetjern, H. (2012). Dealing With A Gendered Economy: Female Drug Dealers and Street Capital. European Journal of Criminology, 9(6), pp. 621- 635.

Sales, P., \& Murphy, S. (2012). How Do You Get Them To Talk To You? Interviewing Drug Sellers in the San Francisco Bay Area. Drugs: Education, Prevention and Policy, pp. 453-461.

Shaw, C. R. \& McKay, H. (2003). Juvenile Delinquency and Urban Areas. Francis T. Cullen and Robert Agnew (Ed.), In Criminological Theory: Essential Readings- Past to Present, Los Angeles: Roxbury Publishing Company, pp. 104-110.

$\mathrm{SAD} / \mathrm{JSR}$

Cilt / Volume 20 Say1 / Number 2 
Sherman, L. (1993). Defiance, Deterrence and Irrevelance: A Theory of the Criminal Sanction". Journal of Research in Crime and Delinquency, Vol.30, No: 4, pp. 445-473.

Skyes, G. \& Matza, D. (1957). The Techniques of Neutralization: A Theory of Delinquency. American Sociological Review, pp. 667-669.

Slattery, M. (2008). Sosyolojide Temel Fikirler. Ü. Tatlıcan, G. Demiriz (Çev.), Ankara: Sentez Yayınevi.

Tannenbaum, F. (1938). Crime and The Community. New York and London: Colombia University Press.

UTSAM Raporlar Serisi: 28. Yasadışı Kenevir Ekimiyle Mücadele. Temmuz 2013.

Ünlü, A. \& Demir, O. (2012). Addict and Non-Addict Drug Dealers in İstanbul, Turkey: Profiles and Differences. International Journal of Human Sciences, 2 (2), pp. 161-173. 